\title{
The influence of genetically modified Bt maize MON 810 in feed mixtures on slaughter, haematological and biochemical indices of broiler chickens*
}

\section{V. Řehout, J. Kadlec'1, J. Čítek, E. Hradecká, L. Hanusová, B. Hosnedlová and F. Lád}

\author{
University of South Bohemia in České Budějovice, Faculty of Agriculture, \\ Department of Animal Genetics, Breeding and Nutrition \\ Studentská 13, České Budějovice, 370 05, Czech Republic
}

(Received 26 September 2008; revised version 24 March 2009; accepted 24 June 2009)

\begin{abstract}
Genetically modified maize hybrid MON 810, which contains a gene for the insecticide protein $\mathrm{Cry} 1 \mathrm{~A}(\mathrm{~b})$, and a conventional non-modified hybrid were tested in three experiments whose objective was to determine their influence on slaughter, haematological and biochemical indicators of ROSS 308 broiler chickens. The chickens were fed a mixture containing 30.0-35.0\% of maize. The nutrional contents in the Bt maize and standard maize were not significantly different. The experimental and control groups gave optimal results in terms of mortality and feed consumption per kg weight gain. The slaughter weight of the chickens at the age of 42 days in the control group and in the group fed with Bt maize fell within the range of 1.800 to $2.000 \mathrm{~g}$ in all three experiments. The results did not show any changes in yield parameters of the broiler chickens. The measured slaughter, haematological and biochemical parameters were not negatively affected by blending Bt maize into the feed mixtures. The haematological and biochemical parameters were found to be within physiological range with no significant changes.
\end{abstract}

KEY WORDS: growth, slaughter, haematology, broilers, Bt maize

\footnotetext{
* Supported by MSM 6007665806

${ }^{1}$ Corresponding author: e-mail: kadlec@zf.jcu.cz
} 


\section{INTRODUCTION}

The classification of genetically modified food and fodder crops has been a much-discussed topic in Europe. Insect-resistant maize MON 810 contains a gene for the insecticide protein Cry1A(b) from the bacterium, Bacillus thuringiensis (Bt), a soil sporulating germ that creates a special protein crystal called Cryprotein in a cell during sporulation. It causes a plant to form its own toxin, killing insects, primarily, the European maize borer (Ostrinia nubilasis).

The objective of a number of experiments dealing with feeding animals using genetically modified plants has been to determine if modified plants are equivalent to conventional variants from an nutritional point of view (Schubbert et al., 1994). Aeschbacher et al. (2005) showed in their experiments with Bt maize in hens and chickens that using Bt maize in poultry feeding did not affect yield parameters. The slaughter weight per bird did not differ between diets. Rossi et al. (2005) carried out a study similar to the one by Aeschbacher et al. (2005). They experimented with the influence of transgenic Bt maize containing a gene for protein Cry1A(b) on the yield factor of chickens and the fate of the nonoriginal DNA from the chicken feed in the chicken digestive system. No significant differences in daily weight, feed intake and conversion were found between the groups of chickens fed with feeding mixtures containing the Bt maize and conventional maize. The nonoriginal DNA from the feed was gradually degraded in the chickens' digestive systems.

The objective of our study was to test the possible influence of feeding genetically modified Bt maize on the slaughter, haematological and biochemical indices of broiler chickens. The comparison of the nutrient composition of modified and non-modified maize was also of some interest.

\section{MATERIAL AND METHODS}

\section{Animals and nutrition}

Three experiments were performed to measure the influence of feeding genetically modified maize on the slaughter, haematological and biochemical indices of broiler chickens. Each of the three experiments had an experimental and control group numbering 100 unsexed one-day-old ROSS 308 broiler chicks. A sex ratio of 1:1 was noted during the individual weighing at the end of the experiments. The average weights of one-day-old broiler chicks were 44.5, 42.0, and $41.0 \mathrm{~g}$ in the experimental groups, $44.5,41.0$ and $42.0 \mathrm{~g}$ in the control groups, in the three experiments, respectively. The chickens were raised on a deep bedding of ground hay, and fed ad libitum. 
The experimental group, as well as the control groups, were fed with feed mixtures of equal components and nutritional composition. The mixtures differed only in the proportion of modified maize and they were divided, according to fattening stages, into mixtures BR1 ( $1^{\text {st }}-21^{\text {st }}$ day of fattening $)$, BR2 $\left(22^{\text {nd }}-37^{\text {th }}\right.$ day of fattening) and BR3 ( $38^{\text {th }}-42^{\text {nd }}$ day of fattening). Modified Bt maize MON 810 (hybrid BOLSA-PR36S30-FAO 370) was fed in the experimental group. Only standard, non-modified maize (hybrid KWS 2376 - FAO 340) was in the mixtures for the control group. Table 1 lists the composition of the used mixtures.

Table 1. Composition of experimental and control feed mixture, $\%$

\begin{tabular}{lrcc}
\hline Components & $\mathrm{BR}^{1}$ & $\mathrm{BR}^{2}$ & $\mathrm{BR}^{3}$ \\
\hline Maize - standard or GM & 31.00 & 30.00 & 35.00 \\
Soyabean extrude & 36.00 & 39.00 & 33.00 \\
Wheat & 24.05 & 27.15 & 28.25 \\
Fish meal (64\%) & 5.00 & - & - \\
Dicalcium phosphate & 2.00 & 2.30 & 2.20 \\
Calcite & 1.00 & 0.50 & 0.50 \\
Salt & 0.25 & 0.35 & 0.35 \\
Aminovitane BR 1-3 & 0.50 & 0.50 & 0.50 \\
DL methionine premix $40 \%$ & 0.20 & 0.20 & 0.20 \\
\hline
\end{tabular}

${ }^{1} 1^{\text {st }}-21^{\text {st }}$ day of fattening; ${ }^{2} 22^{\text {nd }}-37^{\text {th }}$ day of fattening; ${ }^{3} 38^{\text {th }}-42^{\text {nd }}$ day of fattening

There were no differences in the nutritional or energy contents between the respective mixtures. The crude protein content $\left(\mathrm{g} \cdot \mathrm{kg}^{-1} \mathrm{DM}\right)$ and $\mathrm{ME}_{\text {poultry }}$ $\left(\mathrm{MJ} \cdot \mathrm{kg}^{-1}\right)$ in BR1 were 220/13.8, BR2 196/13.9, BR3 183/14.2. The complete composition of the feed mixture is in the possession the authors. The experiments were finished when the chicken achieved day 42 of age. Five cocks and five hens were selected randomly from each group. Whole blood was taken from the wing vein and heparinized. After slaughter, the weight of the carcass (WPC), dressing percentage, the weight of the spleen, liver, kidneys and heart, and the proportion of the weight of the examined organs in WPC were determined.

\section{Analytical methods}

The nutritional composition of the mixtures of standard and modified maize was analysed according to the Weende method. The content of metabolizable energy was determined by calculations from crude proteins, fat, starch and sugar according to the equation (Zelenka et al., 2007):

$\operatorname{ME}\left(\mathrm{MJ} \cdot \mathrm{kg}^{-1}\right)=34.31 \cdot$ fat $\left(\mathrm{g} \cdot \mathrm{g}^{-1}\right)+15.51 \cdot$ crude protein $\left(\mathrm{g} \cdot \mathrm{g}^{-1}\right)+$ $16.69 \cdot \operatorname{starch}\left(\mathrm{g} \cdot \mathrm{g}^{-1}\right)+13.01 \cdot \operatorname{sugar}\left(\mathrm{g} \cdot \mathrm{g}^{-1}\right)$ 
Selected essential amino acids were measured by liquid chromatography. The blood samples were used for determining haematological and biochemical indices: haemoglobin content, erythrocyte and leukocyte counts, total protein, and liver enzyme activity (GMT, AST and ALT). These indices were analysed according to standard norms or according to the manufacturer's methods for particular apparatuses.

\section{Statistical analysis}

The obtained results were processed statistically using Statistica v. 5 software and, for simple classification, scattering analysis according to the following model:

$$
x_{i j}=\mu+\alpha_{j}+e_{i j}
$$

were: $x_{i j}$ - the $i^{\text {th }}$ weight in the $j^{\text {th }}$ selection; $\mu$ - the common part of the mean; $\alpha_{j}$ - expresses the influence of the $j^{\text {th }}$ - level of nutrition factor (1 - GM maize, 2 - control); $e_{i j}$ - the random error.

The differences were tested at the significance levels: $0.05 \geq P \geq 0.01+$; $0.01>\mathrm{P}>0.001++; \mathrm{P} \leq 0.001+++$.

\section{RESULTS}

The nutrient contents in genetically modified Bt maize MON 810 and standard maize are presented in Table 2. The Bt maize and conventional, non-modified maize, showed slight differences in their nutritional contents. The GM maize featured mainly a higher share of individual fibre fractions, i.e. crude fibre, NDF and ADF, but this difference was not significant.

Table 2. Nutrients contents in Bt maize MON 810 and standard maize, $\mathrm{g} \cdot \mathrm{kg}^{-1} \mathrm{DM}$

\begin{tabular}{lrrlcc}
\hline Nutrients & $\begin{array}{c}\text { Maize } \\
\text { standard }\end{array}$ & $\begin{array}{c}\text { Bt maize } \\
\text { MON 810 }\end{array}$ & Nutrients & $\begin{array}{c}\text { Maize } \\
\text { standard }\end{array}$ & $\begin{array}{c}\text { Bt maize } \\
\text { MON 810 }\end{array}$ \\
\hline Dry matter & 909.80 & 911.40 & Sugar & 39.10 & 39.00 \\
Crude protein & 84.10 & 84.00 & ME $_{\text {poultry }}, \mathrm{MJ} / \mathrm{kg}$ & 14.959 & 14.841 \\
Fat & 42.50 & 43.90 & $\mathrm{Ca}$ & 0.28 & 0.40 \\
Fibre & 28.70 & 31.60 & P total & 2.40 & 3.38 \\
NDF & 125.30 & 133.80 & Lysine & 2.30 & 2.30 \\
ADF & 33.40 & 35.60 & Methionine & 1.80 & 1.70 \\
ADL & 13.20 & 13.10 & Methionine + cystine & 3.20 & 3.23 \\
Ash & 13.40 & 18.90 & Threonine & 2.75 & 2.73 \\
N-free extractives & 831.30 & 821.60 & Arginine & 3.54 & 3.52 \\
Starch & 700.30 & 690.50 & & & \\
\hline
\end{tabular}


The broiler chicken weights on control days corresponded with the usual standard values for broiler chickens on days 21,35, and 42 of life and are given in Table 3.

The lack of influence of the GM maize was also evident when assessing chicken mortality in the groups: it did not exceed the values common in chicken fattening in both groups. A statistically significant difference in the dressing percentage between the control group and the experimental group was found only during the first experiment. This phenomenon did not recur during the other experiments (Table 4).

Table 3. Fattening parameters of broiler chickens: feed consumption, $\mathrm{kg} \mathrm{kg}^{-1}$ of liveweight; feed conversion, $\mathrm{kg} \cdot \mathrm{kg}^{-1}$ of weight gain and average slaughter weight, $\mathrm{g}$

\begin{tabular}{|c|c|c|c|c|c|c|c|}
\hline \multirow{2}{*}{$\begin{array}{l}\text { Age of } \\
\text { chickens, } \\
\text { day }\end{array}$} & \multirow{2}{*}{$\begin{array}{l}\text { Fattening } \\
\text { parameters }\end{array}$} & \multicolumn{2}{|c|}{$1^{\text {st }}$} & \multicolumn{2}{|c|}{$2^{\text {nd }}$} & \multicolumn{2}{|c|}{$3^{\text {rd }}$} \\
\hline & & $\begin{array}{l}\text { experiment } \\
\text { group }\end{array}$ & $\begin{array}{l}\text { control } \\
\text { group }\end{array}$ & $\begin{array}{l}\text { experiment } \\
\text { group }\end{array}$ & $\begin{array}{l}\text { control } \\
\text { group }\end{array}$ & $\begin{array}{l}\text { experiment } \\
\text { group }\end{array}$ & $\begin{array}{l}\text { control } \\
\text { group }\end{array}$ \\
\hline \multirow[t]{2}{*}{$21^{\text {st }}$} & feed & 1.64 & 1.65 & 1.65 & 1.56 & 1.68 & 1.47 \\
\hline & $\begin{array}{l}\text { consumption } \\
\text { feed conversion }\end{array}$ & 1.77 & 1.80 & 1.79 & 1.68 & 1.82 & 1.58 \\
\hline \multirow[t]{2}{*}{$35^{\text {th }}$} & feed & 1.97 & 2.05 & 1.77 & 1.81 & 1.85 & 1.78 \\
\hline & $\begin{array}{l}\text { consumption } \\
\text { feed conversion }\end{array}$ & 2.04 & 2.12 & 1.83 & 1.89 & 1.97 & 1.84 \\
\hline \multirow[t]{2}{*}{$42^{\text {nd }}$} & feed & 1.89 & 1.96 & 1.86 & 1.82 & 1.92 & 1.90 \\
\hline & $\begin{array}{l}\text { consumption } \\
\text { feed conversion }\end{array}$ & 1.93 & 2.00 & 1.91 & 1.85 & 1.96 & 1.94 \\
\hline \multicolumn{2}{|c|}{ Average slaughter weight } & 1993 & 2083 & 1878 & 1956 & 1919 & 2000 \\
\hline
\end{tabular}

Table 4. Slaughter results

\begin{tabular}{|c|c|c|c|c|c|c|c|c|c|c|}
\hline \multirow{2}{*}{ Group } & \multirow{2}{*}{ Statistic } & \multicolumn{3}{|c|}{ Slaughter weight, g } & \multicolumn{3}{|c|}{ Weight of carcass, $g$} & \multicolumn{3}{|c|}{ Dressing percentage, $\%$} \\
\hline & & $1^{\text {st }}$ & $2^{\text {nd }}$ & $3^{\text {rd }}$ & $1^{\text {st }}$ & $2^{\text {nd }}$ & $3^{\text {rd }}$ & $1^{\text {st }}$ & $2^{\text {nd }}$ & $3^{\text {rd }}$ \\
\hline $\mathrm{Bt}$ & $\mathrm{x}$ & 2056.4 & 1898 & 2013 & 1504.2 & 1401.5 & 1491.8 & 73.05 & 73.81 & 74.11 \\
\hline maiz & $\mathrm{S}_{\mathrm{x}}$ & 147.50 & 102.74 & 100.10 & 144.21 & 91.95 & 101.42 & 2.527 & 1.584 & 3.646 \\
\hline Control & $\mathrm{x}$ & 2019.0 & 1998.4 & 2083 & 1391.8 & 1466.2 & 1547.2 & 68.84 & 73.32 & 74.34 \\
\hline & $\mathrm{s}_{\mathrm{x}}$ & 111.04 & 120.14 & 220.37 & 137.45 & 105.39 & 150.95 & 4.21 & 1.34 & 1.77 \\
\hline Significa & ance & - & - & - & - & - & - & + & - & - \\
\hline
\end{tabular}

- not significant; $+\mathrm{P}<0.05 ; 1^{\text {st }}$ experiment; $2^{\text {nd }}$ experiment $; 3^{\text {rd }}$ experiment

When evaluating organ size, we did not find any statistically significant or repeated influences of the genetically modified Bt maize on the weight of the examined organs (Table 5). After evaluating haematological and biochemical parameters between the groups, it was found that there was a statistically significant difference in the leukocyte counts and total protein contents only in the third experiment (Table 6). In the first experiment, significantly lower GMT activity as compared with the control group was found. Similar differences were not found in the second and third experiments. Our results for the haematological indicators fell within the physiological range. 
Table 5. Weight of the organs and their rate in $\%$ to weight of poultry carcass (WPC)

\begin{tabular}{|c|c|c|c|c|c|c|c|c|c|c|c|c|c|}
\hline \multirow{3}{*}{ Group } & \multirow{3}{*}{ Statistic } & \multicolumn{6}{|c|}{ Spleen weight and $\%$ of WPC } & \multicolumn{6}{|c|}{ Liver weight and $\%$ of WPC } \\
\hline & & \multicolumn{2}{|c|}{$1^{\text {st }}$} & \multicolumn{2}{|c|}{$2^{\text {nd }}$} & \multicolumn{2}{|c|}{$3^{\text {rd }}$} & \multicolumn{2}{|c|}{$1^{\text {st }}$} & \multicolumn{2}{|c|}{$2^{\text {nd }}$} & \multicolumn{2}{|c|}{$3^{\text {rd }}$} \\
\hline & & $\mathrm{g}$ & $\%$ & $\mathrm{~g}$ & $\%$ & $\mathrm{~g}$ & $\%$ & $\mathrm{~g}$ & $\%$ & $\mathrm{~g}$ & $\%$ & $\mathrm{~g}$ & $\%$ \\
\hline \multirow[t]{2}{*}{ Bt maize } & $\mathrm{x}$ & 2.560 & 0.170 & 2.650 & 0.190 & 3.630 & 0.240 & 47.13 & 3.14 & 36.82 & 2.63 & 61.23 & 4.11 \\
\hline & $\mathrm{s}_{\mathrm{x}}$ & 0.789 & 0.056 & 0.862 & 0.069 & 0.598 & 30.039 & 4.23 & 0.23 & 4.16 & 0.31 & 6.49 & 6.49 \\
\hline \multirow[t]{2}{*}{ Control } & $\mathrm{x}$ & 3.35 & 0.24 & 2.66 & 0.18 & 4.09 & 0.26 & 47.45 & 3.43 & 46.33 & 3.17 & 52.60 & 3.38 \\
\hline & $s_{x}$ & 0.68 & 0.05 & 0.32 & 0.03 & 0.80 & 0.04 & 4.22 & 0.37 & 4.30 & 0.30 & 9.43 & 0.33 \\
\hline \multicolumn{2}{|c|}{ Significance } & + & + & - & - & - & - & - & - & +++ & ++ & + & +++ \\
\hline
\end{tabular}

\begin{tabular}{|c|c|c|c|c|c|c|c|c|c|c|c|c|}
\hline \multirow{3}{*}{ Group } & \multirow{3}{*}{ Statistic } & \multicolumn{5}{|c|}{ Kidney weight and $\%$ to WPC } & \multicolumn{6}{|c|}{ Heart weight and $\%$ to WPC } \\
\hline & & \multicolumn{2}{|c|}{$1^{\text {st }}$} & \multicolumn{2}{|c|}{$2^{\text {nd }}$} & $3^{\text {rd }}$ & \multicolumn{2}{|c|}{$1^{\text {st }}$} & \multicolumn{2}{|c|}{$2^{\text {nd }}$} & \multicolumn{2}{|c|}{$3^{\text {rd }}$} \\
\hline & & $\mathrm{g}$ & $\%$ & g & $\%$ & $\%$ & 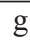 & $\%$ & g & $\%$ & g & $\%$ \\
\hline \multirow[t]{2}{*}{ Bt maize } & $\mathrm{x}$ & 9.00 & 0.64 & 10.82 & 0.72 & 10.240 .69 & & - & 9.00 & 0.64 & 10.82 & 0.72 \\
\hline & $\mathrm{s}_{\mathrm{x}}$ & 0.66 & 0.06 & 1.38 & 0.07 & 2.590 .18 & - & - & 0.66 & 0.06 & 1.38 & 0.07 \\
\hline \multirow[t]{2}{*}{ Control } & $\mathrm{x}$ & 9.26 & 0.67 & 8.64 & 0.59 & 10.050 .65 & - & - & 10.28 & 0.70 & 12.29 & 0.79 \\
\hline & $\mathrm{s}_{\mathrm{x}}$ & 1.96 & 0.15 & 2.53 & 0.17 & 2.600 .13 & - & - & 1.59 & 0.12 & 2.52 & 0.14 \\
\hline \multicolumn{2}{|c|}{ Significance } & - & - & - & - & - & - & - & + & - & - & - \\
\hline
\end{tabular}

- not significant $+\mathrm{P}<0.05$; $++\mathrm{P}<0.01$; $+++\mathrm{P}<0.001$ - the most significant $1^{\text {st }}$ experiment; $2^{\text {nd }}$ experiment; $3^{\text {rd }}$ experiment

Table 6. Haematological and biochemical indices

\begin{tabular}{|c|c|c|c|c|c|c|c|c|c|c|c|c|c|}
\hline \multirow[t]{2}{*}{ Group } & \multirow[t]{2}{*}{ Statistic } & \multicolumn{3}{|c|}{ Haemoglobin, $\mathrm{g} \cdot \mathrm{l}^{-1}$} & \multicolumn{3}{|c|}{$\begin{array}{c}\text { Number of } \\
\text { erythrocytes, } \mathrm{Tl}^{-1}\end{array}$} & \multicolumn{3}{|c|}{$\begin{array}{c}\text { Number of } \\
\text { leukocytes, } \mathrm{g} \cdot \mathrm{l}^{-1}\end{array}$} & \multicolumn{3}{|c|}{ Total protein, $\mathrm{gl}^{-1}$} \\
\hline & & $1^{\text {st }}$ & $2^{\text {nd }}$ & $3^{\text {rd }}$ & $1^{\text {st }}$ & $2^{\text {nd }}$ & $3^{\text {rd }}$ & $1^{\text {st }}$ & $2^{\text {nd }}$ & $3^{\text {rd }}$ & $1^{\text {st }}$ & $2^{\text {nd }}$ & $3^{\text {rd }}$ \\
\hline \multirow[t]{2}{*}{ Bt maize } & $\mathrm{x}$ & 65.80 & 71.02 & 69.85 & 2.56 & 2.60 & 2.28 & 16.95 & 25.88 & 21.23 & 34.57 & 36.04 & 40.22 \\
\hline & $s_{x}$ & 2.21 & 14.45 & 6.83 & 0.26 & 0.76 & 0.42 & 3.27 & 9.24 & 2.79 & 4.25 & 3.13 & 8.12 \\
\hline \multirow[t]{2}{*}{ Control } & $\mathrm{x}$ & 66.30 & 72.55 & 69.56 & 2.57 & 2.08 & 2.06 & 19.70 & 31.92 & 27.10 & 35.49 & 36.38 & 31.20 \\
\hline & $S_{x}$ & 3.87 & 5.42 & 12.06 & 0.36 & 0.35 & 0.30 & 2.44 & 6.08 & 6.35 & 4.29 & 3.00 & 4.11 \\
\hline \multicolumn{2}{|c|}{ Significance } & - & - & - & - & - & - & - & & + & - & - & ++ \\
\hline \multirow[t]{2}{*}{ Group } & \multirow[t]{2}{*}{ Statistic } & \multicolumn{3}{|c|}{$\begin{array}{c}\gamma \text {-glutamyl } \\
\text { transferase } \mu \mathrm{kat} \cdot \mathrm{l}^{-1}\end{array}$} & \multicolumn{3}{|c|}{$\begin{array}{c}\text { alanine } \\
\text { aminotransferase } \\
\mu \mathrm{kat} \cdot \mathrm{l}^{-1} \\
\end{array}$} & \multicolumn{3}{|c|}{$\begin{array}{c}\text { aspartate } \\
\text { aminotransferase } \\
\mu \text { kat } \mathrm{l}^{-1} \\
\end{array}$} & & & \\
\hline & & $1^{\text {st }}$ & $2^{\text {nd }}$ & $3^{\text {rd }}$ & $1^{\text {st }}$ & $2^{\text {nd }}$ & $3^{\text {rd }}$ & $1^{\text {st }}$ & $2^{\text {nd }}$ & $3^{\text {rd }}$ & & & \\
\hline Bt maize & $\mathrm{x}$ & 0.64 & 0.87 & 0.87 & 0.073 & 0.08 & 0.073 & 4.64 & 5.31 & 4.46 & & & \\
\hline \multirow{3}{*}{ Control } & $\mathrm{S}_{\mathrm{x}}$ & 0.25 & 0.39 & 0.31 & 0.02 & 0.02 & 0.02 & 0.58 & 0.80 & 0.47 & & & \\
\hline & $\mathrm{x}$ & 1.03 & 0.72 & 1.12 & 0.061 & 0.069 & 0.071 & 4.54 & 4.81 & 4.75 & & & \\
\hline & $\mathrm{s}_{\mathrm{x}}$ & 0.31 & 0.31 & 0.50 & 0.01 & 0.01 & 0.01 & 0.58 & 0.42 & 0.53 & & & \\
\hline \multicolumn{2}{|c|}{ Significance } & ++ & - & - & - & - & - & - & - & - & & & \\
\hline
\end{tabular}




\section{DISCUSSION}

The analysis of the nutrient contents in the GM Bt maize MON 810 and in the conventional non-modified maize revealed a slight difference. The GM maize primarily featured a higher share of individual fibre fractions, i.e. crude fibre, NDF and ADF, but this small difference did not affect the composition of feed mixtures. Mireles et al. (2000) also compared the composition of Bt maize and genetically non-modified maize. Minimal differences not only in the content of the ash, fat, $\mathrm{N}$-free extractives, nitrogenous compounds, and humidity, but also in true metabolizable energy (TME) and amino acid digestibility were found. Based on a fattening test of these broiler chickens, we stated that the nutritional value of the GM maize is equal to that of non-modified maize.

The same results as Mireles et al. (2000) were also obtained by Gaines et al. (2001) who added GM Bt maize and Roundup Ready maize to feed mixtures for broiler chickens. Apart from yield parameters, the authors also evaluated the coefficients of metabolizable energy digestibility without finding significant differences.

Piva et al. (2001) focused on the yield parameters of broiler cocks fed with mixtures containing Bt maize and isogenetic control maize. The slaughter weight of the cocks from the experimental group was statistically higher than the weight in the control group. The other yield factors were comparable in both groups. The higher slaughter weight of the chickens fed with the Bt maize was caused by a lower level of B1 fumonisine mycotoxin in the GM maize grains.

Taylor et al. (2003) carried out a fattening test with ROSS 508 broiler chickens. The chickens in the experimental groups were fed with two GM maize variants, i.e. insect-resistant MON 810 and herbicide-tolerant MON 88017. The control group was fed with non-modified maize variants. Fattening indicators, slaughter quality, and the content of nutrients in chicken meat were measured in the chickens. The authors did not find any influence of the tested GM maize variants on these measured indicators.

Similarly to the above authors, our results also did not show any deterioration of broiler chicken yield parameters.

When evaluating slaughter parameters, we found, only in the first experiment, a statistically significant higher dressing percentage in the experimental group, which did not occur during the other experiments. When measuring the weights of the chicken internal organs and their share in the weight of the poultry carcass, a change in organ size or its share in the weight of poultry carcass was not found for any organ. The values in all the organs were within the physiological range.

With regard to haematological parameters, we found a statistically significant difference between the groups in the leukocyte count and total protein content 
in blood only in the third experiment. Given that this significant difference was not repeated, the influence of genetically modified maize cannot be considered its cause. The haemoglobin values, erythrocyte and leukocyte counts, measured by us, fall within the physiological ranges given by expert sources: Jelínek and Koudela (2003) give values of 75-120 $\left(\mathrm{gl}^{-1}\right)$ for haemoglobin, 2.1-3.5 $\left(\mathrm{Tl}^{-1}\right)$ for erythrocytes, and 18-30 (G.1-1) for leukocytes of Gallus gallus. Similar values are reported by Härtlová et al. (2002) and Basmacioglu et al. (2005). Raju et al. (2005) determined total protein 4.35 and $2.78{\mathrm{~g} \cdot \mathrm{dl}^{-1}}^{-1}$ at 42 days of age in broilers. Similarly, none of the three monitored liver enzymes, GMT, ALT, or AST, showed any statistically significant differences between both groups. The analysed values are in concordance with the parameters given by: GMT 86.4 and $91.5 \mathrm{IU} \cdot \mathrm{l}^{-1}$, Todorovič et al. (1998), Härtlová et al. (2002) AST $4.49 \mu \mathrm{kat} \cdot \mathrm{l}^{-1}$, ALT $0.05 \mu \mathrm{kat} \cdot \mathrm{l}^{-1}$, Basmacioglu et al. (2005) and Raju et al. (2005).

\section{REFERENCES}

Aeschbacher K., Messikommer R., Meile L., Wenke C., 2005. Bt176 corn in poultry nutrition: physiological characteristics and fate of recombinant plant DNA in chickens. Poultry Sci. 84, 385-394

Basmacioglu H., Oguz H., Ergul M., Col R., Birdane Y.O., 2005. Effect of dietary esterified glucomannan on performance, serum biochemistry and haematology in broilers exposed to aflatoxin. Czech J. Anim. Sci. 50, 31-39

Gaines A.M., Allee G.L., Ratliff B.W., 2001. Nutritional evaluation of Bt (MON810) and Roundup Ready $^{\circledR}$ corn compared with commercial hybrids in broilers. Poultry Sci. 80, Suppl. 1, 51, Abstr. 214

Härtlová H., Bláha J., Koubková M., Draslarová J., Fučíková A., 2002. Influence of heat stress on the metabolic response in broiler chickens. Sci. Agr. Bohemica 33, 145-149

Jelínek P., Koudela K., 2003. Physiology of Farm Animals. MZLU Brno, Brno, pp. 409

Mireles Jr. A., Kim S., Thopson R., Amundsen B., 2000. GMO (Bt) corn is similar in composition and nutrient availability to broilers as non-GMO corn. Poultry Sci. 79, 65-66

Piva G., Morlacchini M., Pietri A., Rossi F., Prandini A., 2001. Growth performance of broilers fed insect-protected (MON810) or near isogenic control corn. Poultry Sci. 80, Suppl. 1, 320, Abstr. 1324

Raju M.V.L.N., Rama Rao S.V., Radhika K., Panda A.K., 2005. Effect of amount and source of supplemental dietary vegetable oil on broiler chickens exposed to aflatoxicosis. Brit. Poultry Sci. 46, 587-594

Rossi F., Morlacchini M., Fusconi G., Pietri A., 2005. Effect of Bt corn on broiler growth performance and fate of feed - derived in the digestive tract. Poultry Sci. 84, 1022-1030

Schubbert R., Lettmann C., Doerfler W., 1994. Ingested foreign (phage M13) DNA survives transiently in the gastrointestinal tract and enters the bloodstream of mice. Mol. Gen. Genet. 242, 495-504

Taylor M.L., Hyun Y., Hartnell G.F., Riordan S.G., Nemeth M.A., Karunanandaa K., George B., Astwood J.D., 2003. Comparison of broiler performance when fed diets containing grain from YieldGard1 rootworm (MON863), YieldGard Plus (MON810 X MON863), nontransgenic control, or commercial reference corn hybrids. Poultry Sci. 82, 1948-1956 


\section{GMO MAIZE-SLAUGHTER AND BIOCHEMICAL TRAITS IN BROILER}

Todorovič M., Mihailovic M., Hristov S., 1998. Effect of high of sodium selenite on activity of certain enzymes in blood plasma of chicks. Vet. Glasnik 52, 411-416

Zelenka J., Heger J., Zeman L., 2007. Recommended Nutriment Content in Feed Mixtures and Nutritive Value of Feeds for Poultry. Mendel's Agriculture and Forest University in Brno, Brno, pp. 78 